\title{
Low-Demand Leisure Activities Domain
}

National Cancer Institute

\section{Source}

National Cancer Institute. Low-Demand Leisure Activities Domain. NCI Thesaurus. Code C129989.

A domain of the Activity Card Sort (ACS) related to low-physical-demand leisure activities that may be part of an individual's routine such as puzzles, quilting, and photography. 